\section{ECOS LORQUIANOS EN LA MEMORIA POÉTICA DEl PARAgUAY: \\ JOSEFINA PLA, AUGUSTO ROA BASTOS Y HÉRIB CAMPOS CERVERA}

\author{
PACO TOVAR
}

Nunca estuvo Federico García Lorca en Paraguay; sí llegó a orillas del Plata y deslumbró también a ciertos poetas del mediterráneo paraguayo, dejando en la zona un rumor lírico, tantas veces manejado con fuerza épica, moldeado en imágenes sonoras dispuestas a reclamar cómplices, no tahúres de salón amable o canallas desbocados. El reclamo lorquiano, derivado en ocasiones hacia el histrionismo, habría de estimular el sentido mágico de ciertas conciencias rioplatenses, ayudándoles en la aventura poética que apenas se iniciaba en Paraguay, todavía entretenido en balbuceos poéticos forjados en su propio caldo de cultivo.

\section{TILDES ANDALUZAS}

Resulta oportuno evocar la procedencia confesional del quehacer literario emprendido por Lorca, desplazando éste hacia los márgenes. Al mismo autor cuenta, con la ayuda de ilustraciones selectas, que la naturaleza del arte se descubre al compás de las voces, cuando son originales; al ritmo del artificio, cuidadosamente organizado con sinceridad; y sostenido por el duente, pulsado con rigurosa libertad, pero modulado por costumbre en las fronteras de un medio que tiende a recluirlo en atmósferas tabernarias, o emplearlo como iniciados.

No es un secreto que, en parte sustancial, esa dimensión artística descubre en Lorca objeto de estudio folclórico en laboratorios de querencias significativas por el cante jondo, de amplio espectro, perfiles andaluces y rasgos primitivos, apreciando menos, con ese registro, su pariente flamenco, de reciente sabor común, fórmula postiza y talante local. El primero esgrime en su favor trágicos mestizajes de rancia nobleza; el segundo utiliza las claves del anterior para construir nuevos destellos de ingenio en los mercados del compadreo. namentaciones, tañe, con gracia popular, firme emoción y pulso simbólico, los colores del espíritu, guardando memoria de los viejos tiempos; sus postizos armónicos emplean fáciles recursos para dibujar matices y trazar arabescos en piezas que recuerdan escenas costumbristas. Ambos pueden ser gitanos, pero de solera unos y dudoso calibre los demás, quizás porque los últimos sólo alcanzan formas definitivas en el XVIII.

Se da el nombre de cante jondo a un grupo de canciones andaluzas cuyo tiempo genuino y perfecto es la seguirilla gitana, de las que derivan otras canciones aún conservadas por el pueblo, como los polos, martinetes, carceleras y soleares. Las coplas llamadas malagueñas, granadinas, rondeñas, peteneras, etc., no pueden considerarse más que consecuencias de las antes citadas, y por tanto su arquitectura como por su ritmo difieren de las otras. Estas son las llamadas flamencas. ${ }^{1}$

Esta lección de música remite a las apreciaciones de Falla, un maestro para quién los sistemas musicales del cante jondo disponen Aquél, de simple apariencia que no elude or-

\section{Paco Tovar}

Catedrático de Literatura Hispanoameautor de libros sobre Augusto Roa Bastos (1987 y 1993), y de una visión múltiple de autores y problemas de la literatura hispanoamericana del siglo $\mathrm{XX}$ (Contrapunto, 2002). Ha publicado además numerosos artículos sobre vanguardias, Vicente Huidobro, Juan Carlos Onetti, Mario Monteforte, Alejo Carpentier, etc. Es miembro fundador de la Asociación Española de Estudios Literarios Hispanoamericanos y Secretario General de la misma desde 1992 hasta la actualidad.

I Federico García Lorca, «El cante jondo», Obras Completas, Aguilar, Madrid, 1974, T. I. , pág. 971. ricana en la Ǔniversidad de Lleida. Es
Ecos lorquianos en la memoria poética del Paraguay: y Hérib Campos Cervera Josefina Pla, Augusto Roa Bastos 


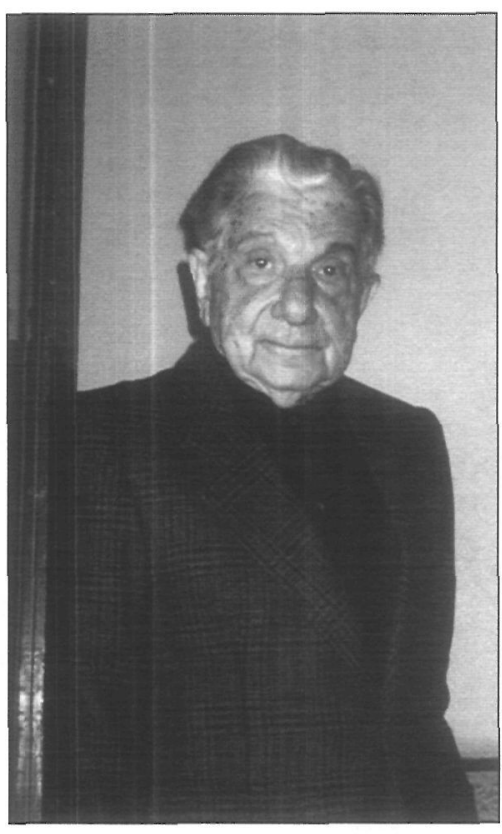

Augusto Roa Bastos (Foto: Mar Langa).

2

«El cante jondo», op. cit., pág. 975.

3

Ibidem, págs. 977 y 982.

4

«El cante jondo», op. cit., pág. 986.

Ecos lorquianos en la memoria poética del Paraguay:

Josefina Pla, Augusto Roa Bastos y Hérib Campos Cervera PACO TOVAR de un sólido pasado con origen en la India, escuchándose siempre con ellos

...una maravillosa ondulación bucal, que rompe las celdas sonoras de nuestra escala atemperada, que no cabe en el pentagrama rígido y frío de nuestra música actual, y abre en mil pétalos las flores herméticas de los semitonos.

El cante flamenco no procede por ondulación, sino por saltos; como en nuestra música tiene un ritmo seguro y nació cuando ya hacía siglos que Guido d'Arezzo había dado nombre a las notas.

[El cante jondo es], pues, un rarísimo ejemplar de canto primitivo, el más viejo de toda Europa, que lleva en sus notas la desnuda y escalofriante emoción de las primeras razas orientales. $^{2}$

Pero esa rancia procedencia del cante jondo no debe confundirse con una forma trasplantada; mejor entenderla como un injerto que permite asomarse a cierta coincidencia de orígenes y obedece a la acumulación de tantos hechos históricos con raíces en la tierra. Rara vez superan, por enharmónicos, la sexta escala, repitiendo con obsesión motivada una misma nota, siendo este un procedimiento acusado en ciertas fórmulas de encantamiento o antiguos recitativos que se identifican con los inicios del lenguaje.

Se puede afirmar definitivamente que el cante jondo, lo mismo que en los cantos del corazón de Asia, la gama musical es consecuencia directa de lo que podríamos llamar gama oral.

Son muchos los autores que llegan a suponer que la palabra y el canto fueron una misma cosa.

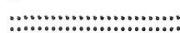

Vean ustedes, señores, la trascendencia que tiene el cante jondo [...]. Es hondo, verdaderamente hondo, más que todos los pozos y todos los mares que rodean el mundo, mucho más hondo que el corazón actual que lo crea y la voz que lo canta, porque es casi infininito. Viene de razas lejanas, atravesando el cementerio de los años y las frondas de los vientos marchitos. Viene del primer llanto y del primer beso. ${ }^{3}$

Reconocer en las palabras una filiación sonora conduce a desvelar la maravilla comprendida en sus poemas, no en los podados con las tijeras del romanticismo y postroman- ticismo, sino en los crecidos en árbol genésico, donde se encuentran las infinitas gradaciones del Dolor y la Pena, puestas al servicio de la expresión pura y exacta. Esas coplas de original factura tienen un fondo común: el Amor y la Muerte..., pero un amor y una muerte vistos a través de la Sibila.

Transmisora potencial de los secretos, secreto ella misma, la hembra misteriosa continúa recibiendo preguntas sobre pregunta, guardando celosamente las soluciones de cualquier enigma; cuando más, los insinúa para vestir cantos que eluden recurrir al medio tono, detalle propio de la honda expersión andaluza, tan profunda y extrema que suele dirigir sus gritos a las estrellas o sembrar sus besos en el polvo rojizo de los caminos. Semejante a los trinos del ruiseñor sin ojos, los murmullos del cante jondo pertenecen a los ciegos, y por eso, tanto sus textos como sus melodias antiquísimas tienen su mejor escenario en la nocbe. Rodeadas de oscuridad y encerradas en sí mismas, esas formas sonoras son también las flechas de un formidable arquero azul cuya aljaba no se agota jamás. Tremendas visiones nocturnas de aguda punta y certero blanco, no son populares por carecer de autor conocido, restando así suspendidas en el vacío y lejos de la consciencia; pertenecen a las gentes comunes, porque ellas saben adaptarlas a su sensibilidad.

Los poetas que hacen cantares populares enturbian las claras linfas del verdadero corazón; y ¡cómo se nota en las coplas el ritmo seguro y feo del hombre que sabe gramática! Se debe tomar del pueblo nada más que sus últimas esencias y algún que otro ritmo colorista, pero nunca imitar fielmente sus modulaciones inefables, porque no hacemos otra cosa que enturbisrlas. Sencillamente, por educación.

Los verdaderos poemas del cante jondo no son de nadie, están flotando en el viento como vilanos de oro y cada generación los viste de color distinto, para abandonarlos a las futuras.

Los verdaderos poemas del cante jondo están en sustancia sobre una veleta ideal que cambia de dirección con el aire del Tiempo.

Nacen porque sí, son un árbol más en el paisaje, una fuente más en la alameda. ${ }^{4}$

La mirada lorquiana se desplaza ya hacia la mujer, Pena con forma humana y línea definida; reconoce el panteísmo del hondo decir enharmónico, recogido en abanicos temáticos de carácter melancólico; y tiende a escuchar con 
atención las voces sentidas, que se ofrecen a cambio de nada y no admiten comparaciones; tampoco son cantos tratados con justicia...

...y vuelvo a insistir en la infamia que se comete con ellos, relegándolos al olvido o prostituyéndolos con la baja intención sensual o con la caricatura grotesca. Aunque esto ocurre exclusivamente en las ciudades porque afortunadamente para la virgen Poesía, y para los poetas, aún existen marineros que cantan sobre el mar, mujeres que duermen a sus niños a la sombra de las parras, pastores ariscos en las veredas de los montes; y echando leña al fuego, que no se ha apagado del todo, el aire apasionado de la poesía avivará las llamas y seguiran cantando las mujeres bajo las sombras de las parras, los pastores en sus agrias veredas y los marineros sobre el ritmo fecundo del mar. ${ }^{5}$

El gusto de Lorca por los aciertos sonoros del instrumento popular no desprecia la calidad del verdadero artificio poético. Ese imposible acuerdo deja de ser una paradoja cuando se entienden los juegos originales de otro maestro andaluz: Góngora, de superior envergadura y profunda dimensión.

Ángel de luz o espíritu de tinieblas, Góngora forma parte de un debate que pretende marcar las diferencias entre los poetas llamados populares o impropiamente nacionales, y los poetas llamados propiamente cultos o cortesanos, discusión liviana porque carece de motivos, aunque baste revisar la historia literaria española para confirmar el enfrentamiento y las maneras de argumentarlo, discusiones que habrá de resolver Lorca una vez localizado el necesario espacio para situar las coincidencias:

...quiero hacer constar que no creo en la eficacia de esta lucha ni creo en lo de poeta italianizante y poeta castellano. En todos ellos hay, a mi modo de ver, un profundo sentimiento nacional. La indudable influencia extranjera no pesa sobre sus espíritus. El clasificarlos depende de una cuestión de enfoque histórico. ${ }^{6}$

Esa perspectiva conciliadora descubre entre pares a Garcilaso, modelo renacentista en el panorama hispano, y Castillejo, de tendencia medieval en paisajes compartidos. También aproxima el quehacer de Lope y las tareas de Góngora, ambos figuras emblemáticas del barroco nacional, uno más inclinado hacia el desnudo expresivo; mejor embozado el otro. En cualquier caso, la coherencia poética del segundo, teñida de franqueza, es una de sus virtudes, defendida con soledad aristocrática.

Consiguieron arrinconar a Góngora y echar tierra a los ojos nuevos que venían a comprenderlo durante dos largos siglos en los que nos han estado repitiendo... «no acercarse, porque no se entiende...» Y Góngora ha estado solo como un leproso de fría luz de plata, con la rama novisima en las manos esperando las nuevas generaciones que recogieran su herencia objetiva y su sentido de la metáfora.?

Porque la clave de la escritura gongorina se encuentra en los acertados empleos de la metáfora, injertada en cada una de sus obras para comprimir significados y enriquecer los juegos del lenguaje, advirtiendo que estos merecen estudio; se pierden con lecturas rápidas. Góngora, usando sus imágenes, no viene a buscarnos, como otros poetas, para ponernos melancólicos, sino que bay que seguirlo razonablemente. Fue él mismo, desde sus versos, una revolución lírica que supo responder a la nativa necesidad de belleza, y conduce a un original modelado del idioma.

Inventa por primera vez en el castellano un nuevo método para cazar y plasmar las metáforas, y piensa, sin decirlo, que la eternidad de un poema depende de la calidad y trabazón de las imágenes.

Ya no podía crear poemas que supieran al viejo gusto castellano; ya no gustaba la sencillez heroica del romance. Cuando para no trabajar miraba el espectáculo lírico contemporáneo, lo encontraba lleno de defectos, de imperfecciones, de sentimientos vulgares. Todo el polvo de Castilla le llenaba el alma y la sotana de racionero. Sentía que los poemas de los otros eran imperfectos, descuidados, como hechos al desgaire. ${ }^{8}$

La cuestión del método deriva del propio criterio gongorino, de paladar exquisito rehacio al color local y feroz enemigo de mimetizar lecturas, aún las más entrañables entre las clásicas. Se debe a determinadas consideraciones sostenidas por un espíritu escultórico situado en un ambiente extraatmosférico, desvelando en última instancia su incapacidad para sentir a secas una realidad real, siendo por el contrario dueño absoluto de la realidad
5 Ibidem, pág. 989.

6 F. García Lorca, «La imagen poética de don Luis de Góngora», Obras Completas, T.I., op. cit., pág. 1004.

7

Ibidem, pág. 1005.

8 Ibidem, pág. 1006.
Ecos lorquianos en la memoria poética del Paraguay: Josefina Pla, Augusto Roa Bastos y Hérib Campos Cervera 
«La imagen poética de don Luis de Góngora», op. cit., pág. 1008.

10

Ibidem, pág. 1008.

11 Ibidem, págs. 1011 y 1013.

12 «La imagen poética de don Luis de Góngora», op. cit., pág. 1014. poética, en su más amplia dimensión. Se identifica Góngora como profesor en los cinco sentidos corporales, que ordenará rigurosamente: vista, tacto, oído, olfato y gusto, trazando así las pautas del conocer poético, que otra vez entiende de reglas y acuerda con un decir metafórico repleto de alma.

Para que una metáfora tenga vida necesita dos condiciones esenciales: forma y radio de acción. Su núcleo central y una redonda perspectiva en torno de él [...]. La metáfora está siempre regida por la vista (a veces por una vista sublimada), pero es la vista la que la hace limitada y le da su realidad...

El tacto enseña la calidad de sus materias líricas. Su calidad... casi pictórica. Y las imágenes que construyen los demás sentidos están supeditadas a los dos primeros. ${ }^{9}$

Las apreciaciones gongorinas de Lorca se amplían para comprender un sistema de relaciones que se inicia, cómo no, en la naturaleza de esas metáforas, todavía semejante al léxico de los diccionarios, cuando permanece aislada del entorno expresivo; dispuesta para la sintaxis dentro de una composición, sometida a normas, moldeada con bellos perfiles y siempre organizada para unir dos mundos antagónicos por medio de un salto ecuestre que da la imaginación.

La originalidad de don Luis de Góngora, aparte de la puramente gramatical, está en su modo de cazar las imágenes, que estudió utilizando sus dramáticos antagónicos por medio de un salto ecuestre que da el mito. ${ }^{10}$

Ésta es una de las claves dominantes en poesía, y tratada con privilegio en la de Góngora, ya que sus figuras tienden a desvelar la condición simbólica de los objetos líricos, no importa la entidad, el tamaño o la materia.

Góngora trata con la misma medida todas las materias, y así como maneja mares y continentes como un cíclope, analiza frutas y objetos. Es más, se recrea en las cosas pequeñas con más fervor.

Góngora no crea sus imágenes sobre la misma Naturaleza, sino que lleva el objeto, cosa o acto, a la oscura cámara de su cerebro y de allí salen transformados para dar el gran salto sobre el otro mundo con que se funden. Por eso su poesía, como no es directa, es imposible de leer entre los objetos de que habla. ${ }^{11}$
El camino y los aciertos merecen situar el quehacer gongorino entre los más altos, porque enseña un mundo interior, que no puede espiarse fuera, logrando seducir con toda su potencia; también liberar con todas sus fuerzas. Así lo mira Lorca; con parecido acento se atreve a contarlo; y de semejante cuño son las estrategias de cazador nocturno en lejanisimo bosque.

El poeta debe ir a su cacería limpio y sereno, hasta disfrazado. Se mantendrá firme contra los espejismos y acechará cautelosamente las carnes palpitantes y reales que armonicen con el placer del poema que lleva entrevisto [...]. Su fantasía cuenta con sus cinco sentidos corporales [...]. Intuye con claridad que la naturaleza que salió de las manos de Dios no es la naturaleza que debe vivir en poemas, y ordena sus paisajes analizando sus componentes. Podríamos decir que pasa a la naturaleza y sus matices por la disciplina del compás musical.12

Vuelve Lorca a su referente sonoro aplicándolo ahora a su verdad gongorina, modelo de armonía imposible, pero con hondo sentido, tremendamente lúcida, controlada en sus formas, moldeada con inteligencia y repleta de imaginación, que no es un estado sino un espacio aún por vestir del que se vuelve como cuando se regresa de un país extranjero. No es un despropósito entender que Góngora es un clásico empeñado en ofrecer las claves de una revolución transformada en metáforas. El poeta barroco, tan oscuro, sólo narra historias, dibujando apenas su esqueleto y arropándolas en la carne magnífica de las imágenes. Por eso se habla de dos Góngoras:

El Góngora culto y el Góngora llanista. Las literaturas y sus catedráticos lo dicen. Pero una persona con un poco de percepción y sensibilidad podrá notar, analizando su obra, que su imagen siempre es culta. Aún en los romancillos más fáciles construye sus metáforas y sus figuras de dicción con el mismo mecanismo que cumple en su obra genuinamente culta. Pero lo que pasa es que están situadas en una anécdota clara o un sencillo paisaje, y en su obra culta están ligadas a otras a su vez ligadas, y de ahí su aparente dificultad. ${ }^{13}$

El gusto que declara Lorca por las formas cultas del barroco gongorino no mengua su querencia por las expresiones de origen popular, entendiendo así los contrastes de una 
poesía en tensión, digna de estudio, repleta de sensibilidad y capaz de reconocer su duende en todo lo que tiene sonidos negros:

...el misterio, las raíces que se clavan en el limo que todos conocemos, que todos ignoramos, pero de donde nos llega lo que es sustancial en el arte. Sonidos negros dijo el hombre popular de España y coincidión con Goethe, que hace la definición del duende al hablar de Paganini, diciendo: «Poder misterioso que todos sienten y ningún filósofo explica».

Así, pues, el duende es un poder y no un obrar, es un luchar y no un pensar [...]. Es decir, no es cuestión de facultad, sino de verdadero estilo vivo; es decir, de sangre; es decir, de viejísima cultura, de creación en acto. $^{14}$

Afirmaba Nietzsche que las obras de cualquier artista son el resultado de una lucha contra el propio diablo, no la gracia de los ángeles, que sólo iluminan desde lo alto, o la complicidad de las musas, tan caprichosas y tantas veces sordas a los reclamos. Ese enfrentamiento con una figura demoniaca, más próxima a sus antecedentes socráticos o cartesianos; menos identificada con los de perfil religioso y máscaras literarias, sirve para valorar sus consecuencias, despejar tópicos, rechazar geometrías y advertir derrotas, estas últimas posibles al no disponer de planos y estrategias que garanticen el triunfo, descubierto por el iniciado cuando nota que el espíritu vence a la materia pobre; también cuando estimula en el ignorante una auténtica emoción.

Ese juego violento de poder logra desarrollarse con mayor gracia en los campos de la música, la danza y la poesía hablada, artes que necesitan un cuerpo vivo que interprete por qué nacen y mueren de modo perpetuo y alzan sus contornos sobre un presente exacto. De alguna manera, Lorca establece así prioridades, decantándose a favor de la honda complejidad y simple apariencia, sin negarle aprecios esenciales al complicado artificio y exquisita sensibilidad. La sorpresa pulsa las entrañas; la admiración se provoca con inteligentes maneras; ambas son mestizas y pueden llevar la muerte, el amor y la libertad a cuestas, pero una se mantiene con los pies en la tierra y la otra se mueve desde una imaginación construída a propósito. Aquélla es de honda naturaleza; la segunda de creativa fuerza. En cualquier caso, ¿dónde está el duende?, quizás en algún sitio, cuando

...el arco vacío entre un aire mental que sopla con insistencia sobre las cabezas de los muertos, en busca de nuevos paisajes y acentos ignorados; un aire con sabor de saliva de niño, de hierba machacada y velo de medusa que anuncia el cosntante bautizo de las cosas recién creadas. ${ }^{15}$

Tan ambigua en su exacta definición, esa perspectiva permite afirmar que Góngora y el cante hondo son hijos de la misma madre, pero no siameses. Quienes pretenden situarlos en los extremos, tampoco se equivocan, pero ayudan a entender la naturaleza del círculo mágico que representa el poema, fórmula que

...consiste en estar siempre enduendado para bautizar con agua oscura a todos los que miran, porque con duende es más fácil amar, comprender, y es seguro ser amado, ser comprendido, y esta lucha por la expresión y por la comunicación de la expresión adquiere a veces, en poesía, caracteres mortales. ${ }^{16}$

\section{VUELTA (PARÉNTESIS OPORT'UNO)}

Al principio se anotaba que Lorca nunca estuvo en Paraguay; sí en tierras del Plata, injertándose mejor desde entonces en la conciencia de un público y no pocos autores rioplatenses. De hecho, Lorca desembarca en Buenos Aires cumplido el otoño de 1933, insistiendo en aclarar que su arte no es popular, sino con aire aristocrático, aunque reconoce que va impregnado de raza. También es un hecho que, se aleja de Buenos Aires iniciada la primavera de 1934, declarando en esa ocasión que, durante su estancia, ha tenido la suerte de echar raíces porque ha descubierto

...algo vivo y personal; algo lleno de dramático latido, algo inconfundible y original en medio de sus mil razas y atrae al viajero y lo fascina. Para mí ha sido suave y galán, cachador $y$ lindo y he de mover por eso un pañuelo oscuro, de donde salga una paloma de misterosas palabras en el instante de mi despedida. ${ }^{17}$

Por esa época Lorca ya se debajan sentir en América: alguna de sus piezas teatrales se re-
13

Ibidem, pág. 1022.

14

F. García Lorca, «Teoría y juego del duende», en Obras Completas, op. cit. T. I., pág. 1068.

15

"Teoría y juego del duende», op. cit., pág. 1079.

16

Ibidem, pág. 1076.

17

F. García Lorca, «Discurso de despedida de Buenos Aires», Obras Completas, T.I., op. cit. pág. 1166.

Ecos lorquianos en la memoria poética del Paraguay: Josefina Pla, Augusto Roa Bastos y Hérib Campos Cervera. PACO TOVAR 
Josefina Pla, «Siete definiciones de la poesía a través de la obra de Federico García Lorca», El País, Asunción, 24 de febrero de 1945. Pág. 10. cibían con interés, celebrándose con éxito; desplegó su don de gentes; e hizo gala de su histrionismo. No es un despropósito entender que todas esas proyecciones, de orden literario, cualidades escénicas y dimensión humana, tuvieron su eco en aquella zona del Plata; también en los cotos de su interior mediterráneo, donde alcanzó a instalarse en la memoria de una vanguardia poética inaugurada por Josefina Pla, Augusto Roa Bastos y Hérib Campos Cervera.

\section{LECTURA Y HOMENAJE}

Uno de los trabajos más lúcidos de Josefina Pla se ocupa de García Lorca, no para ordenar frases laudatorias o efectuar ejercicios gimnásticos de simple carácter alusivo, sino para definir, con talante literario e impresiones de lector, la misma poesía. El texto, publicado en febrero de 1945, da noticias del asunto a tratar en sus párrafos liminares:

Los versos de Lorca - avenida de álamos de platarebrillan inmovilizados en solsticio lozano. Cuando acabamos de leer sus versos tenemos la sensación de haber hallado de nuevo la poesía. Que es como decir que deseamos una nueva definición. Sus poemas tienen acento de presagio, porque todos ellos son voz prestada a lo que fue, y el presagio no es sino un remorder de lo definitivamente olvidado. Vienen de eternidad y van a eternidad, bogando por el río efímero de nuestra sangre.

Así, herederos de sus versos - laberinto entretejido de soles desvelados y lunas y mares por abrir - hemos de componer nosotros mismos la clave para atravesar su recinto metafórico y alcanzar el reducto final, donde la verdad acorralada se da vida y más semejante a uno mismo. ${ }^{18}$

Establecidas las señas, Josefina Pla ordenará sus definiciones, regidas todas por una cifra mágica y cada una de ellas mediante una palabra: cintra, nombre que identifica en arquitectura los puntales de apoyo situados en en los vanos de acceso a las diferentes estancias de una construcción, imposible de sostener $\sin$ la ayuda de ese elemento estructural, compuesto para la ocasión de piezas poéticas extraídas en yacimientos lorquianos: Libro de poemas (1921), Primeras canciones (1922), Romancero gitano (1927) y Poeta en Nueva York (1929-1930). Esos pocos materiales sirven para mantener la estructura de un trabajo que re- mite a sus antecedentes lorquianos y alcanza a definir la poesía.

La primera cimbra remite a «Cantos nuevos», y permite el acceso a las estancias del sentimiento melancólico, esa bilis negra de origen visceral reconocida en el quehacer poético bajo la máscara que le proporciona un término clásico de amable eufonia y diferente explicación: como hecho científico, por ser una secreción del organismo que responde a los estímulos del exterior; como materia de estudios sicológicos, por ser la manifestación de una angustia residual, derivada ésta principalmente, según la escuela freudiana, del impulso sexual, ya escondido en la memoria, y la evocación de la muerte, siempre presentida. En cualquier caso, todos esos registros forman parte de un yo que se debate a solas con sus duendes, tratando de expiar viejas culpas o de recuperar la inocencia primitiva. En este orden de cosas, la literatura no será sino el esfuerzo de la bumanidad por olvidar, recordándolo, que está desnuda; la poesía, el intento de un regreso imposible.

«Madrigal de verano» y "Romance de Thamar y Amnón» sostienen la segunda cimbra, que da entrada al salón del erotismo, más próximo a la sugerencia que a las descripciones minuciosas de la actividad carnal. Plantear ese rasgo diferenciador no es gratuito, porque la versión directa satisface carencias en la especie animal, engañándola con sus farsas; la simbólica formula un rito que exige cómplices entre los miembros de una raza sensualmente satisfecha, pero dispuesta a identificarse frente a los verdaderos artificios. La segunda cumple su función de círculo mágico, encerrando en sí misma el tremendo espectáculo de la vida y de la muerte, ambos enlazados e inagotables también en la poesía, donde todas las formas advierten que no es lo que es, sino lo que está llegando a ser.

Cimbra de entrada al salón de los juegos adolescentes manchados de vejez son «Remanso», «remansillo» y "canción de las siete doncellas». Contemplar esas representaciones permite enfrentarse a la historia, no como testimonio, sino desde su raíz mítica, ya alumbrada por las musas de Hesiodo, el Daimón de Sócrates y los fuegos de Byron, Shelley, Heine, Hölderlin, Schiller y De Vigny. Encontrarse con tan entrañables sombras evita soberbias y ayuda a crear poesía, que se define ahora como becho ontológico de concepción; su sentido 
se bace claro en esa implícita multiplicidad posible de formas.

Es «Palimsesto» cimbra del propio hermetismo, también localizado en «Elegía del silencio», donde todo se encuentra fuera de la realidad y dentro de lo que algunos llaman vicio escenográfico, sin entender que dentro de ese espacio suspendido está la explicación del hecho representado y la claridad de su poesía, sombra que - para seguir el paralelismo con los teoremas de óptica -llega basta el cuerpo luminoso.

«La canción del mariquita» es cimbra que permite ver qué el color tiene el sonido, saborearlo y recuperar su melodía, ya repleta de aromas intensos y verdaderos ensueños poéticos. Ese proteísmo sensorial es señal de vida por ser visión onírica, "asíntota del sueño", del mismo modo que la palabra es la asintota de la idea.

Situar la cimbra en «Romance del muerto de amor» es reconocer la sala grande ocupada por el Romancero gitano, lugar de cita con toda la poesía lorquiana de ropa popular y profundas metáforas, éstas repletas de perfiles raciales, cuerpos sensuales, manantiales cristalinos, amables rumores, humildes secuencias, rayos de sol, reflejos de musgo..., todos brindando luego con las oscuras etnias, tensos sensualismos, impresiones urbanas y paisaje artificial de Poeta en Nueva York. No basta evocar en ese juego a Walt Whitman; también cuentan, sin agotar la nómina de recuerdos, Fernando de Rojas, Calderón, Moreto, el Arcipreste de Hita, Santa Teresa o Ignacio de Loyola, todos instalados en el sentimiento trágico de una poesía que es la forma más ajustadamente sensible a la muerte.

Última cimbra, la «Oda a Dalí» descubre el gabinete secreto de los estiletes líricos, armas de un escritor que penetran en la porción más múltiple, estriada e inquietante de la lírica; también en la más oscura, no por falta de luz, sino porque se despliega en múltiples formas cromáticas, filtradas, como en la «oda a Walt Whitman», en la sombra arterial de su árbol venoso. Lo que importa es entender que que la poesía es una sola, pero distinta para cada uno, ahí está la verdad de su signo y el espacio de cita con la eternidad. De ahí surgen las siete definiciones de la poesía, sintetizadas en que no tiene ninguna, motivo suficiente para rendir al poeta muerto el único homenaje

cifrado que se le debe, ahora reducido al trozo que la concluye:

Federico García,
Por doce puertas rojas la muerte te quería.:.:.:.:.:.:.:
Las abrió como doce
Versos de rojas consonantes.
- Eran la muerte larga que tu verso conoce-
Doce bocas de versos te cantaban, amantes.
La besaste con labios de doce versos rojos.
Ella, amorosa y lenta, se te acostó en los ojos. ${ }^{19}$

\section{APUNTES Y DESPEDIDA}

Seña de identidad paraguaya más profunda es la música, afirma por convicción Augusto Roa Bastos, dispuesto a reconocer que ese rasgo, junto al de la propia tradición oral, puede compartirse con otros pueblos que dispongan de suerte semejante, pero no alcanzarán el acento dominante que modula el Paraguay, porque así, dice Roa,

...traduce nuestro temperamento y revela nuestra sensibilidad en sus tonalidades peculiares, en su color fundamental. La música es como la piel de nuestra vida nacional; una piel tensa y vibrante bajo la cual se perciben los latidos del corazón de nuestro pueblo, se adivinan sus impulsos y se intuyen sus ansias. ${ }^{20}$

Esa característica remite a los primeros tiempos de una historia que surge por los resquicios de la memoria común, articulada en sonidos hondos y modulada voz profunda, ambos al ritmo continuo del sentimiento y al compás de un rito que estimula a sus artistas más primitivos. Firmes contra el espejeamiento de formas y apariencias, cada uno de esos señores confirma

...la prolongación de una gran línea de generación estética que no puede detenerse en él y que debe fluir como una vena irrepresable por el cauce siempre activo de la emoción popular de cuyo hondón surge y al cual torna invariablemente. ${ }^{21}$

Ya logró asombrar el instinto musical paraguayo al español recién llegado, aconsejándole usurpar ese recurso para reducir a sus indígenas, que cantando nacieron y cantando habrán de morir, sin perderse del todo por el camino y dando noticias de su entrañable
19

Josefina Pla, «Federico García Lorca», El País, Asunción, 12 de julio de 1944.

De clara influencia lorquiana son también, entre otras, las piezas: «El poema del creciente» $y$ «Lo casada infiel». La primera, de registro popular, fechada en 1940 e incluída en De la imposible ausente (inédito en vida de la poeta, pero recogido en sus Poesías completas de Josefina Pla, edición de Miguel Ángel Fernández, El Lector, Asunción, 1996); la segunda, de 1978, en forma de soneto, comprendida en La llama y la arena (Alcándara, Asunción, 1985).

20

Augusto Roa Bastos, «La música y el carácier nacional paraguayo», Suplementos Anthropos. Antologías Temáticas (Augusto Roa Bastos, Presentación y selec ción de textos: Paco Tovar) n 25, 1991, pág. 72. El original forma parte de una conferencia del escritor pronunciada en Asunción (Asociación de Músicos del Paraguay, 20 de diciembre de 1946), cuyo resumen se publicaría inicialmente en El País (Asunción, 7, enero, 1947); más tarde en la Revisfa del Afeneo Para guayo ( $n^{\circ}$ 17, febrero-marzo, 1947).

21

«La música y el carácter nacional paraguayo», op. cił., pág. 73.

\footnotetext{
Ecos lorquianos en la memoria poética del Paraguay:

Josefina Pla, Augusto Roa Bastos y Hérib Campos Cervera PACOTOVAR
} 
Ibidem, pág. 73.

23

Ibidem, pág. 75.

24

«La música y el carácter nacional paraguayo», op. cit. pág. 78.

25

A. Roa Bastos, «Sobre el sentido ascético de la poesía nueva», Poesías reunidas, Miguel Ángel Fernández (ed.), El Lector, Asunción, 1995, pág. 261. El original remite a noviembre de 1943 (Revista del Ateneo Paraguayo, año $\left.2, n^{\circ} 8\right)$.

26

Ibidem, pág. 263.
Ecos lorquianos en la memoria poética del Paraguay:

Josefina Pla, Augusto Roa Bastos y Hérib Campos Cervera PACO TOVAR fuerza en cualquiera de sus tareas y momentos cotidianos.

Entonces las noches se llenan de bordoneos pueblerinos y de canciones hondas que parecen brotar de los surcos y los ramajes, enredados al chisporroteo hondulante de las luciérnagas.

Hay desgraciadamente muchos paraguayos que no saben leer, pero en compensación hay muchos menos que no saben tocar la guitarra.

Tenemos, pues, entonces, en orimer término, un instinto, una vocación, que es decir casi todo. ${ }^{22}$

Razón de ser y vocaciones de estar configuran así los perfiles de un folklore lúdico y tremendo, dando las pautas de unas relaciones difíciles entre los dos ámbitos de una sola cultura con acento guaraní y rostro castellano, figura esta de un Jano particular empeñado en divertirse y dispuesto a mantener sus formas clásicas.

El pueblo no utiliza ya la música para acompañarse en los momentos de expansión de unos ritmos más o menos vivos, y de unas melodías más o menos pegadizas. Sus fiestas indudablemente se han dignificado. Por sobre los bailes campesinos, sus canciones, sus fogosos zapateos, su rumor alegre y expansivo, flota en la guaranía, en el Kyre/yn o en la misma polca, algo nuevo que llena el alma sencilla del hombre del pueblo de esa satisfacción indefinible que es ya presencia del placer estético logrado por la autenticidad del $\operatorname{arte}^{23}$

Difícil acuerdo mantener islas y construir puentes en tierra con raíces mestizas y tensión permanente, salvo en esa música repleta de matices que se debate, por cuestiones de lengua, entre la armonía oral y los armónicos de la escritura; peor solución cuando el problema se desvía con asuntos de cuño social, debatidos en forjas dominantes, por decreto a golpes, y talleres dominados, condenados al cierre por defunción y silencio. Esas cuestiones también juegan en el tapete literario y la de menor entidad espera una suerte que sólo puede proporcionarle la sedimentación paulatina de la literatura en español, decantada en filtros paraguayos, o la aparición de un talento genial, con registro guaraní, ambos en ejercicio de caballeros, no en lucha excluyente. Bastantes demonios tienen los dos para entretenerse de poder a poder con falsos duendes. Mejor reunirse sumando ángeles oscuros en
Un refugio transparente por el ensueño, un espejo cristalino para el rostro de nuestra alma, un templo para los ritos conmovidos de la emoción y una trinchera para la batalla del hombre con su destino. ${ }^{24}$

Roa no apuesta en ese truco por la tensión estática, sorda en su pulso musical, tímida en sus voces y copiada de rasgos, propia de talantes conservadores, gestos conformistas y talante nostálgico, cuando no sometido. Invita a seguir en trincheras literarias, manejar nuevas armas y vestir uniformes de trabajo, defendiendo el instinto de perpetuación con verdaderos artificios y reales invenciones. Se trata de liberar la historia creándola con palabras; intuyéndola, no pensándola esa nueva poesía que, entre otros, cita en su favor a Neruda, Alberti y, cómo no, a Lorca, todos comprometidos en un hecho literario, tan primitivo como el dolor de hoy, verbo de mañana. Esa expresión estética sentida, de misterioso origen y cuidada forma prefiere su condición ascética, otro modo de entender el estilo barroco no a la manera de Góngora sino cortando a medida los vestidos que cubren la materia del espíritu, no para deshumanizarlo, sino por humanarlo una vez destemporalizado en su más amplia realidad poética.

El objeto de la poesía no es trasuntar la realidad, sino acrecer sus fronteras. No es un espejo. Es una antorcha. La poesía empieza donde lo real termina, y su misión es crear nuevas realidades. Harto se concibe que para el poeta moderno, lo irreal no es lo que no tiene existencia absoluta, sino sencillamente lo que no la tiene todavia. ${ }^{25}$

Velada, la cita de Josefina Pla en una de sus definiciones; también la memoria de Lorca, con sus imágenes; ambas bajo el palio de la metáfora, de nuevo elemento imprescindible como cimbra que ha de sostener la construcción poética, resolviendo un problema de fuerzas contrarias. El decir con metáforas no es una

Oposición de dos entidades afines, sino, inversamente, la superación de esa relación de identidades que hay entre el objeto y su representación. No interesa en la metáfora que lo metaforizado conserve un aire familiar con su objeto, lo que interesa es que la metáfora lleve en sí misma incapsulados objeto y sujeto, es decir, que sea idéntica a sí misma. ${ }^{26}$ 
No olvida Roa que para conseguir ese equilibrio de fuerzas ensimismadas cuenta con el buen uso de los mitos, profunda historia y verdadera fantasía en molde religioso y con valor simbólico, a semejanza de la escritura injertada de esas formas reales que deben ser bien leídas para entender lo que dicen

Esa lectura de la realidad por medio del mito no es, entonces, como muchos creen, una huida al pasado, una regresión a la matriz intemporal de la fábula, el refugio de una inmovilidad fetal. Esta capacidad de una lectura simbólica a todos los niveles de la realidad permiten integrar el pasado, el presente y el futuro en la magnitud de un tiempo viviente en el cual el individuo y la sociedad pueden intuir en un relámpago el secreto de su identidad y plantearse sus interrogantes fundamentales, tal como lo demuestra precisamente la función simbólica del lenguaje. ${ }^{27}$

La correspondencia lenguaje-mito, o la inversa, es una relación misteriosa que se repite entre la verdad y la mentira, la claridad y las sombras, la vieja tradición y la cultura aprendida, el poder y la servidumbre, las formas y el sentido, el amor y la muerte..., todas reunidas en la poesía para para ofrecer el espectáculo de la vida y la muerte cantadas a solas dentro del propio círculo mágico, este repleto de armónicos, murmullos y fantasías extraídas de una conversación abierta con la realidad y sus artificios. En ese espacio cuentan los hondos sonidos de Lorca.

\section{ECOS DE ESCRITURA}

como un mendigo ciego

yo imploraba en secreto tu voz, tus alas rotas,

tu vida de soldado destruida,

el resplandor visible de tu fuego

que en el costado izquierdo de la patria,

lejos o cerca de ella,

era su antorcha melodiosa,

su combatiente estrella

y el pulso musical de su destino.

.............................:

Tu voz canta y solloza en las distancias

Y fulguran celestes tus pupilas

Sobre el pavés de los jazmines,

Sobre las alas de los pájaros,

Sobre los labios que te llaman...

:...............................:

Entre los rascacielos te despido
De esta ciudad a orillas del río como mar,

Con su pueblo profundo

En cuyo umbral

Te inclinaste a dormir alucinado

Bajo el cielo del sur.

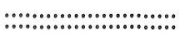

Mi mano de poeta

Queda clavada aquí, sobre tu cruz,

Por siempre.28

Son trozos de una pieza construída por Augusto Roa Bastos para despedir con homenaje a un poeta amigo, muerto en Buenos $\mathrm{Ai}$ res: Hérib Campos Cervera; también para iniciar un retiro voluntario de la poesía.

Estoy aquí, sin voz y sin presencia;

Limpio de luz con mis duras anclas

Mordiendo las tinieblas de granito

Que duermen en la boca de mis túneles.

Te encuentro en este claro mediodía cavando

Cauces, donde el latido del agua no tenía

Ningún trigo guardado para que diera el surco

Su pan de voz morena, maduro de presente.

Traes un alba de música distinta en la garganta:

Se siente que no quieres llevar la misma luna

Que solicita el zumo vegetal de otras voces.

Por eso: porque vienes sin ley de gratitud

Tu verso tiene tanta cargazón de llamados

Para el Clavel y el Agua y el Viento que manejas.

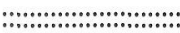

Y que la liberada palabra de los años

Te encuentre siempre al pairo del sol más justiciero,

Para que no haya herrumbre sobre tu nombre claro:

Capitán de esta aurora que no tiene silencios... ${ }^{29}$

Es parte de la respuesta que el mismo Hérib Campos Cervera, aún vivo, dirige a Roa, en diálogo consigo mismo, y nunca hubiera podido escribir si no rompe, como hizo, las reglas del tiempo y la ley de los muertos, liberando en esas formas su fuerte intuición poética. Los interlocutores, en sus juegos de palabras también disponen de un testigo común en los ecos que les proporcionaría Lorca.

«Responso» es la pieza de Hérib Campos Cervera que más se aproximan a los registros lorquianos, tanto por el semejante empleo de recursos literarios como por descubrir las emociones de su autor ante la muerte. El poema no responde al simple testimonio de
A. Roa Bastos, "El buen uso de los mitos», Suplementos Anthropos, op. cit., pág. 79. El original se publicaría en Acción (Asunción, IV, 12, octubre, 1971).

28

A. Roa Bastos, "Adiós a Hérib Campos Cervera», El naranjal ardiente, Diálogo. Libros de la Pirririta, Asunción, 1960.

29

Hérib Campos Cervera, "Capitán de esta aurora», Ceniza Redimida, Editorial Tupá, Buenos Aires, 1950, págs. 57-59.
Ecos lorquianos en la memoria poética del Paraguay: Josefina Pla, Augusto Roa Bastos y Hérib Campos Cervera PACO TOVAR 
30

Hérib Campos Cervera, "Responso", Poesías completas y otros textos, Miguel Ángel Fernández (ed.), El Lecior, Asunción, 1996, págs. 199-200. El editor incluye esta pieza, fechada en 1947, bajo el epígrafe de «Poemas no incluídos en Ceniza redimida».
Ecos lorquianos en la memoria poética del Paraguay: Josefina Pla, Augusto Roa Bastos y Hérib Campos Cervera una experiencia dolorosa, cuidadosamente descrita y capaz de reclamar la atención de curiosos ante un suceso irreparable; logra crear su atmósfera, ofreciendo la visión trágica de un espectáculo donde cuenta tanto la realidad del hecho como su memoria, uno y otra desarrollados en la materia un rito trágico de origen histórico, perfil sentimental, formas adecuadas y condición simbólica.

Precedida de una dedicatoria, donde se identifica la persona que merece el recuerdo del escritor, la naturaleza campesina de ese personaje, el soporte que ha de servir para dibujar los versos y el carácter de oración que se le reconoce a estos últimos, la estructura fragmentada del poema permite seguir los diferentes cuadros de su representación, alternando en ellos las formas de apariencia culta y las de aspecto popular, ambas repletas de metáforas acuñadas en tono trascendente. Así da cuenta en primer lugar de una escenografía, un personaje y unos rasgos de este último, ya situados fuera del tiempo y dentro de las sombras, todo ello de mágicas dimensiones concéntricas y con oportuno vigilante:

En memoria de Juan de Dios Talavera -un "mensú» que conocí en vida $y$ muerte-, escribo en el agua del río inmenso, este Responso.

I

Lo custodian cien círculos transparentes y un pájaro. Y una desesperada soledad de domingo.

Baja por la corriente, viajero de su muerte,

Llevando sus dos párpados con su noche y su frío.

Cuando labios helados llamaron al desvelo

Y la sangre se fue por su camino:

Dos violetas nocturnas y un clavel sin memoria

Le ajustaron la máscara sobre el rostro dormido.

Manos de obscura ciencia y oficio mercenario

Le buscaron un túmulo de muros imprecisos,

Y hoy navega sin brújula, sin puerto y sin sosiego,

-viajero de su muerte-, por el río.

II

Manos de jazmín antiguo;

Brazos de intensa madera.

Sombra nocturna del pelo

Bajo la luna bermeja.
Presencia helada de hierro

Que torvamente navega,

Cruzando sobre el silencio

De una guitarra sin cuerdas.

Ay, ;muchacho navegante!

Ay iJuan de Dios Talavera!

¡Cómo te nombro y te sueño

frente al alba sin estrellas!

¿Por qué me vienes bajando

llenos los ojos de niebla?

¿Dónde están tu faz de cobre

y esa garganta morena

que moría en las bordonas

cuando cantabas tu queja?

¡Cómo te llevo conmigo,

Juan de Dios de mi tristeza!

¡Cómo arañan mis recuerdos

tus dos manos de azucenas! ${ }^{30}$

En segundo término, se repite el esquema anterior, esta vez para reconocer la escritura como materia representada, encuadrada en tiempo verbal presente y con amplia muestra central en verbo pasado:

\section{III}

Todo aquello que puede nombrar a un ser venido

Por un claro sendero de música y claveles,

Vivía en este dulce paraguayo que baja

Solo y vestido de temprana muerte.

Vivió un juego de magia inaccesible:

Bajo las catedrales del oro y de la fiebre,

Lo cuidaba una imagen sin fatiga y sin párpados,

Velando siempre...

Todavía las muertes juntas custodiaban su vida:

La bota de cien leguas de la lluvia perenne;

El universo azul de las orquídeas

Y el aire poderoso de los infiernos verdes.

(Todo vivía allí, pero ay, amigos,

el tiempo de vivir estaba ausente)

\section{IV}

Hierros de voces opacas

Le salieron al encuentro:

Una guitarra invisible

Puso su nombre en el viento. 
Embrujos de pelo obscuro

Se encendieron a lo lejos

$Y$ un llamado de jazmines

Le amortajó los recuerdos.

Bajo la luz de la frente,

Sollozaba un largo silencio.

Ay!, en el medio del río

Ya el corazón está quieto.

Frente a la tarde impasible

Corre el agua, va corriendo:

Juan de Dios, sigue que sigue,

Solo, sin voz y sin puerto. ${ }^{31}$

Resulta evidente que, por sus paralelismos formales y con tanta semanza de imágenes, logra distanciarse del calco por los detalles que introduce, añadiendo matices de particular esencia paraguaya teñida de muerte, dolor y sangre propios del mediterráneo paraguayo, reducido a unos pocos términos. En última instancia, Hérib Campos Cervera es un poeta de su tierra, reservándole a Lorca un puesto de privilegio en la memoria poéti- ca que le corresponde, vuelta a resumir en trozos de emocionado recuerdo vivo, dirigido en fórmula epistolar a Federico, ya difunto compañero:

Federico: los años han secado tus carnes; En ellas han penetrado gusanos de la tierra;

Pero tu voz remota, poderosa de símbolos, Como el mar, no está muerta...

Entre un vuelo de albatros y un tumulto de estrellas, Se volvió al infinito tu fiesta de canciones.

Cuando pasen mil años, junto a esta misma piedra Que destacó tu estampa sobre el telón atlántico, Aún estaré esperando que otra música análoga Taladre el laberinto de cal de mis oídos. ${ }^{32}$

\section{PENÚLTIMO COMPÁS, Y SUERTE}

Una muy breve conclusión para tanto aparejo: Lorca, se dice, nunca fue a Paraguay... Mentira. Cuando poco, estuvo allí con Josefina Plá, desde Roa Bastos y según Hérib Campos Cervera.
31

«Responso», op. cit., págs. 200201.

32

Hérib Campos Cervera, "Federico», Ceniza redimida, op. cit., págs. 51-52. 